\title{
鼻アレルギー減感作治療における 喘息の影響
}

\author{
鵜飼幸太郎・坂倉 康夫・大井 益一 - 山田 清治 \\ 伊藤由紀子・坂田 富美・三吉 康郎
}

\section{Effects of Immunotherapy on Nasal Allergy with or without Extrinsic Asthma}

\author{
Kotaro Ukai, Yasuo Sakakura, Masuichi Ohi, Seiji Yamada \\ Yukiko Ito, Fumi Sakata and Yasuro Miyoshi \\ (Mie University)
}

This study was undertaken to evaluate the effects of hyposensitization in 435 patients on the nasal allergy with or without extrinsic asthma. There were 360 patients with nasal allergy uncomplicated with asthma. Specific and nonspecific IgE, numbers of eosinophils in the blood and nasal secretion, and subjective nasal symptoms were employed as parameters.

The incidence of abnormally high serum $\operatorname{IgE}$, specific $\operatorname{IgE}$ and blood eosinophils was found to be higher in the patients with nasal allergy with asthma than those uncomplicated with it. The difference in the incidence was statistically significant. There was no significant difference in the incidence of the patients with abnormally increased eosinophils in both blood and nasal secretion between the patients with or without asthma.

During the course of hyposensitization over one year, it was found that it was only the number of eosinophils in the nasal secretion which was significantly decreased. In the patients with nasal allergy uncomplicated with asthma, the appearance of the blocking antibody was significantly increased after a one-year course of immunotherapy. Other parameters were not changed in the patients with or without asthma.

It was concluded that the parameters examined were almost identical and that nasal allergy with or without asthma might be improved by hyposensitization over one year.

$$
\text { は じめに }
$$

アレルギー学の進歩に伴い鼻アレルギーや気管支喘息の発症機序が次第に解明されつつある. して鼻アレルギーに代表されるレアギン型アレルギー反応においては, Coombs and Gell1 ${ }^{11}$ が分類 した I 型の即時型アレルギーの他に補体成分が関与している可能性 ${ }^{2)}$ や T cell が重要な役割を演 
じていることが ${ }^{34)}$ 分って来た。一方気管支喘息を外因性，内因性，混合性に分類5)するならば，ア トピ一性で IgE 抗体が関与し, 皮内反応が陽性で遺伝的素因のあるものを外因性, 抗原が不明で 皮内反応陰性, 遺伝的素因がなく, 気道感染をしばしば合併しているものを内因性, てれら二つを 明確に分類出来ないものを混合性とし, 気管支喘息の約 $70 \%$ とされている ${ }^{6)}$ 外因性は I 型アレルギ 一の他に而型が関与している7 と云われている.

鼻アレルギーには外因性気管支喘息を合併していることがしばしばあり，乙の両者はいずれあ基 本的に I 型の即時型アレルギー反応が主体をなしていると考えるととが出来る．乙れらに対する治 療は現在までのとてろ, 原因抗原による減感作療法が最もよいとされている. 鼻アレルギーに対す る減感作治療を行う場合に鼻アレルギー単独群と気管支喘息合併群とでは両者の症状改善に一致を みないことはしばしば経験される，そこで著者らは気管支喘息の合併もしくは既往の有無が鼻アレ ルギー患者の減感作治療に如何なる影響を及ぼすか臨床的検討を加えてみた.

\section{対象と方法}

昭和 53 年 1 月より 12 月未までの 1 年間に三重 大学耳鼻咽喉科アレルギー外来にて検査を受 け, 減感作治療を受けているか, 又はてれから 受けようとする 435名を対象とした. 研究方法 は問診より現在む気管支喘息の発作があり, 内 科又は小児科にて加療しているグループ，以前 に喘息の発作があり, 小児科医の治療を受けた ことがあるがこの数年間は全く発作が起ってい ないグループ，そして気管支喘息には全く罹患 したことがないグループの 3 群に分類し, 初診 時又は再検査時の血中好酸球, 鼻汁中好酸球, 一元拡散法やR I S T 法による血清 $\operatorname{IgE}$ 值, RAST SCORE，皮内反応を利用した遮断抗体 陽性率等と治療期間との関係について検討して みた。再検査の時期は原則として減感作治療が 維持量に達した時と, その後 6 ケ月でとに行っ た. 花粉症の場合はシーズン中の検査結果のみ を参考とした。

鼻汁中好酸球検査は, サランラップに採取し た鼻汁を Hansel 液で染色後1000倍の視野で検 鏡し，4 個以下を-，5〜20 個を+，21〜100
個をH，101 個以上を州として分類した. 又末 梢血中好酸球は血液像より好酸球 100 分率を求 めた。一元拡散法による血清 $\operatorname{IgE}$ 濃度の测定 にはトリパルチゲン (ヘキスト)を用いた. 又 R I S T 值や RAST SCORE の測定には IgE テストシオノギとRASTシオノギを用いた. 遮断抗体価の測定は皮内反応を利用した直接 法8)にて行った. 各種パラメーターは正常範囲 より幾分高めの值を陽性として検討した。 即ち 血清 $\operatorname{IgE}$ は $1000 \mathrm{I} U$ 以上, 血中好酸球は $8 \%$ 又は $10 \%$ 以上, R A S Tは 3 以上, 鼻汁中好酸 球は 1000 倍の視野で 5 個以上, 遮断抗体は $\times 1$ 以上を陽性とした。 自覚症状の改善度は, 効果 判定基準をごく簡素化するために，くしゃみ発 作, 水性鼻漏, 鼻閉について各 1 点を与え, そ れらの症状が消失あるいは著るしく改善された 昜合を 0 点とした. 3 が 0 かまたは 1 に， 2 が 0 に，1が 0 になれば有効之判定し， 3 が 3 か 2 に, 2 が 2 か 1 の場合を無効と判定した. 推 計学的な分析は $\chi^{2}$ 検定を用いた。

\section{研 究 結 果}

対象とした 435名のうち, 気管支喘息を合併 した症例は19名で全体の $4.4 \%$ に見られた. 又 気管支喘息に罹患した既往のある症例は56名, $12.9 \%$, 鼻アレルギー単独の症例は 360 名, 82 .
7\%であった（図 1 ）。

気管支喘息を合併した19名の年令別, 性別分 布は図 2 右に示している.すべての症例は30才 までで全体の $1 / 3$ が10才までの小児に見られた。 
喘息既往を有する鼻アレルギー患者56名の分布 は図 2 左に示す。全体の $\frac{2}{3}$ は男性で, 特に10才 台の男性が最む多く21名, $37.5 \%$ に見られた。

図 3 は鼻アレルギー単独 360 名の年令別性別分 布を示している．男女比はほぼ 1 対 1 であるが 男性では10才台に最む多く見られたのに対し女 性では20才台，30才台に多く見られた。

鼻汁中の好酸球数之血中好酸球との関係を検 討すると図 4 のようになる. 図 $4 \mathrm{a}$ は喘息合併 群の初診時之 1 年以上減感作治療時の值を比較 している. 血中好酸球が $8 \%$ 以上で鼻汁好酸球 数が十以上即ち 5 個以上を示す症例数の割合は 初診時 $56.3 \%, 1$ 年以上治療で $54.5 \%$ 之改善傾 向は見られなかったが, 図 $4 \mathrm{~b}$ に示す鼻アレル ギー単独群ではこの割合が，初彰時の $43.2 \%$ に 比べ 1 年以上の治療で $19.7 \%$ と有意に改善して いた（ $\mathrm{P}<0.005 ）$ 又 1 年未満では不変である が， 1 年以上の減感作治療を行った場合，喘息 合併群に比し, 鼻アレルギー単独群は血中好酸 球 $8 \%$ 以上で鼻汁好酸球数が 5 個以上を示す症 例数が少く, $\mathrm{P}<0.025 て ゙$ 有意差を認めた。

一元拡散法による血清 IgE 值と血中好酸球 との関係について検討してみた. 図 5 は喘息合

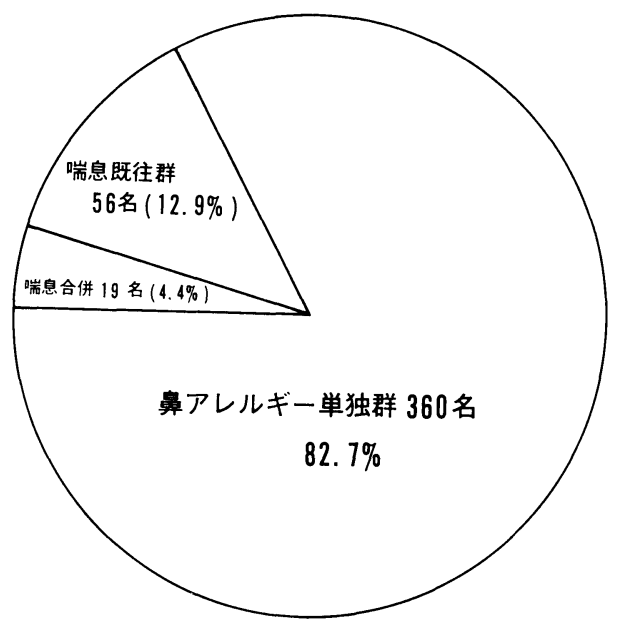

図 1 症例数分布

併群と鼻アレルギー単独群の初診時の值の比較 である. 血清I $\mathrm{gE}$ が $1000 \mathrm{I} \mathrm{U} / \mathrm{ml}$ 以上で血中好 酸球 $10 \%$ 以上の症例の割合は喘息合併群 $33.5 \%$ に比べ鼻アレルギー単独群では $5.7 \%$ と有意に 低く（P<0.005），てれに反し $1000 \mathrm{I} \mathrm{U} / \mathrm{ml}$ 以 下で $10 \%$ 以下の症例の割合は，喘息合併群 $33 \%$ に比べ単独群は $71.2 \%$ と有意に高率に認められ た $(P<0.005)$. 又 1 年以上減感作治療を行っ

(韻アレルギー十気管支喘息の既往あり)

(鼻アレルギー十気管支喘息)

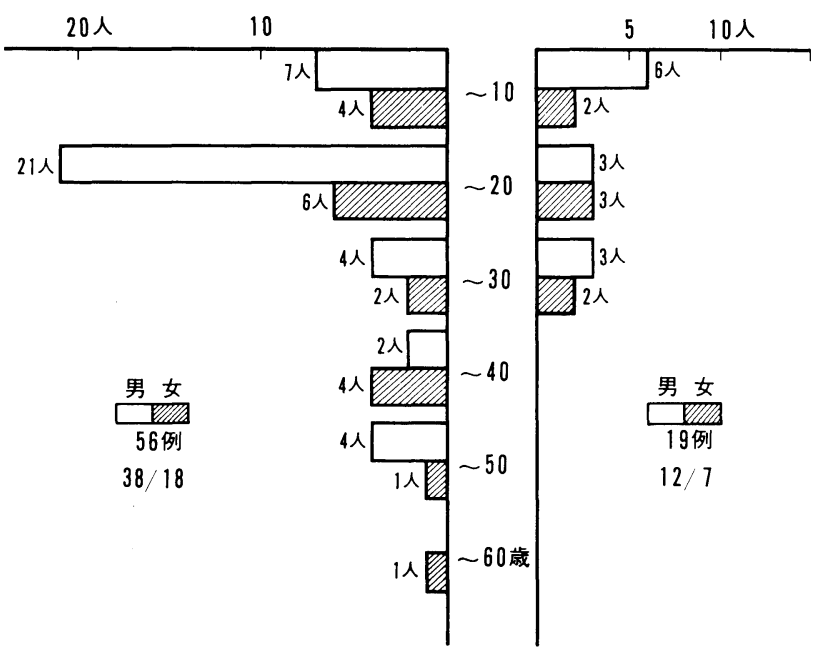

図 2 年令別, 性別分布 


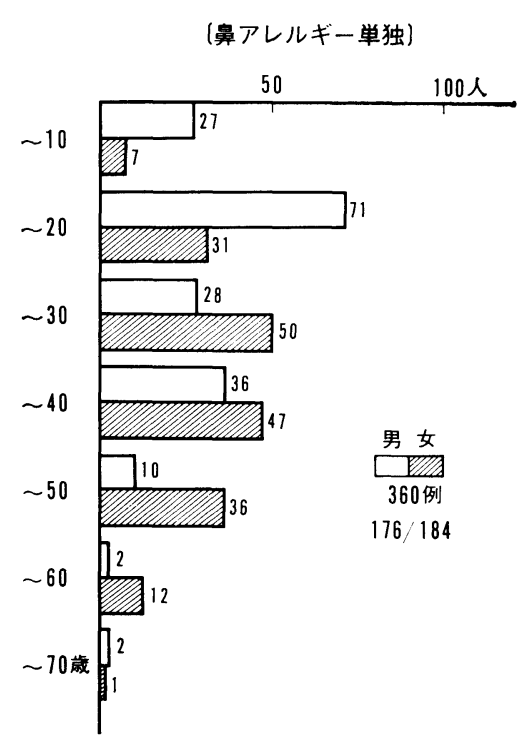

図 3 年令別, 性別分布

た場合でも，初診時と同様の結果を得た。減感 作 1 年以内と 1 年以上を比べてみると，いづれ の群においても差は認められなかった。

RAST SCORE とR I S T 值との関係について 検討してみた（図 6 ). RAST SCORE 3 以上 でR I S T值が1000単位以上の症例は喘息合併
群で42.9\%に見られたが, 鼻アレルギー単独群 では $13.3 \%$ と著るしく少く $(\mathrm{P}<0.025)$, 逆に RAST SCORE 2 以下でR I S T值が1000単位 以下の症例は喘息合併群では14.3\%であったが 鼻アレルギー単独群では $50.6 \%$ と著るしく高率 に認められた（ $\mathrm{P}<0.025)$. このような傾向は 喘息既往群と鼻アレルギー単独群との間にも認 められ，乙れらはそれぞれ統計的に有意差があ った（ $\mathrm{P}<0.005$ 及び $\mathrm{P}<0.01 ）$.

鼻汁好酸球数と治療期間について検討してみ ると，図 7 に示す如く喘息合併群も鼻アレルギ 一単独群も 1 年以上減感作治療を行うと鼻汁中 好酸球数が+即ち20個以上の症例数は減少し特 に鼻アレルギー単独群では統計的有意差があっ た $(\mathrm{P}<0.005)$.

血中好酸球之治療期間との関係について検討 したのが図 8 である。1 年末満減感作治療群に 抒いて，血中好酸球が $10 \%$ 以上を示す症例は喘 息合併群で $62.5 \%$ と高率に認めたが，アレルギ 一単独群では $16.9 \%$ と低く，乙れには統計的有 意差があった $(\mathrm{P}<0.01)$. 1 年以上の減感作治 療により鼻アレルギ一単独群では， 1 年未満治 療群に比べあまり変らず12.3\%であったが，合
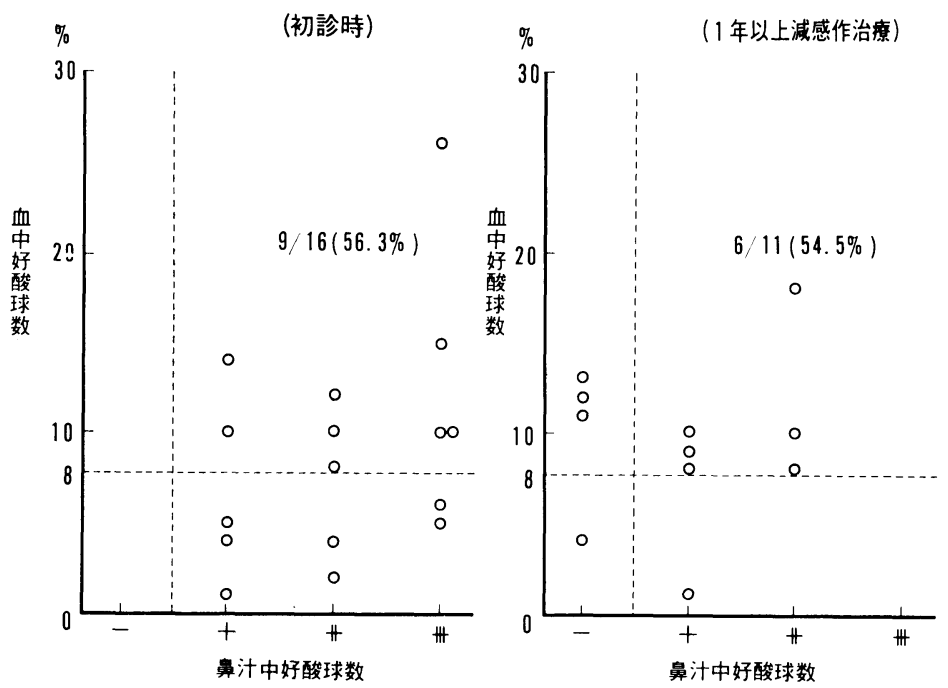

図 $4 \mathrm{a}$ （気管支喘息合併群）

図 4 鼻汁中好酸球数と血中好酸球 


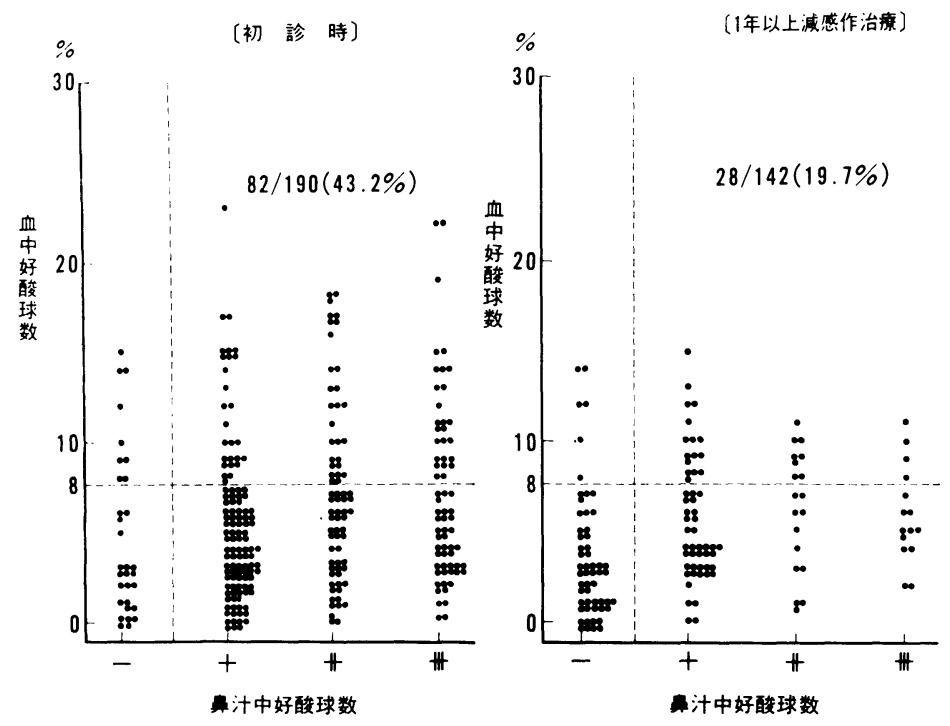

図 4 b （鼻アレルギー単独群）
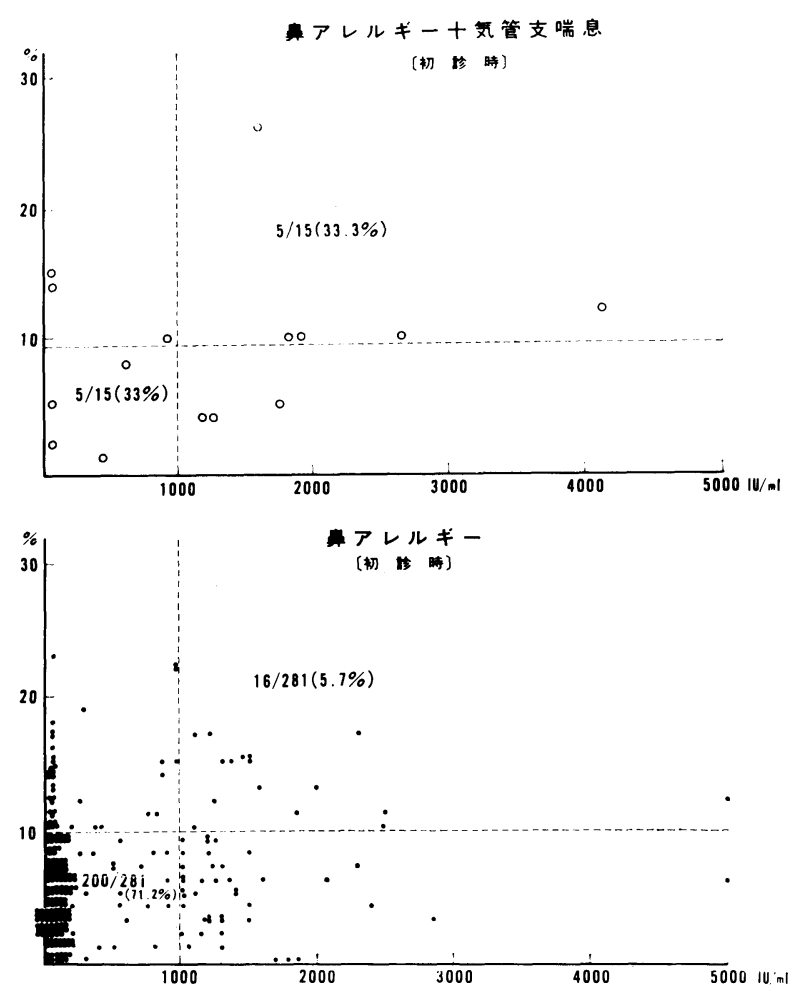

図 5 血清 $\mathrm{IgE}$ 值と血中好酸球 

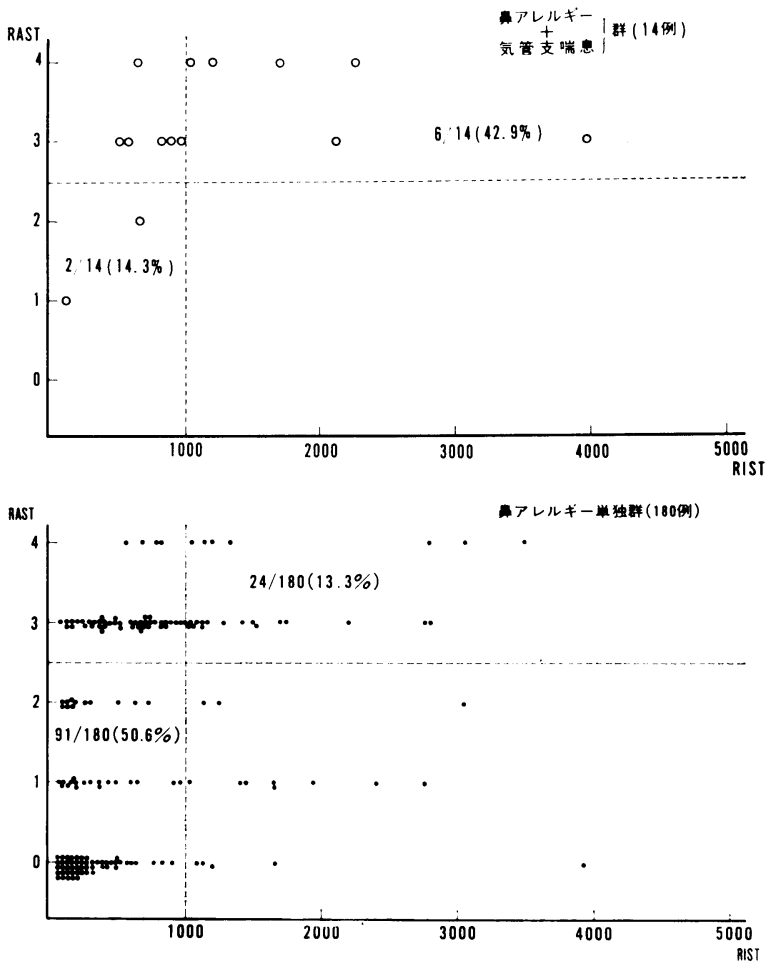

図 6 RAST SCOREと RIST 值
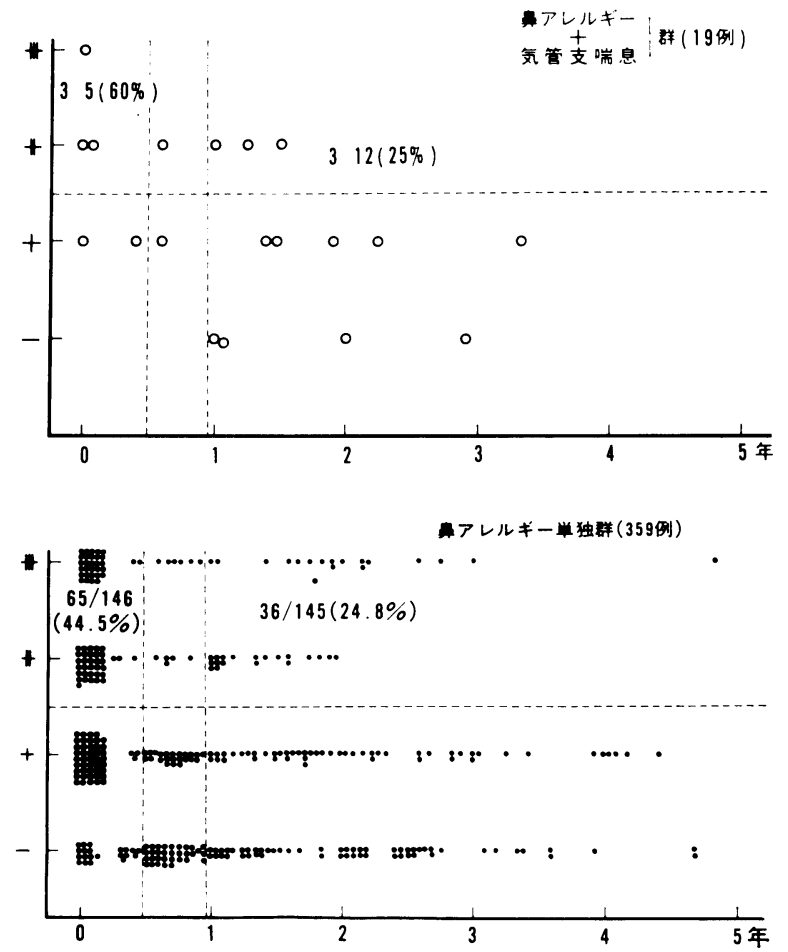

図 7 鼻汁好酸球数と治療期間 

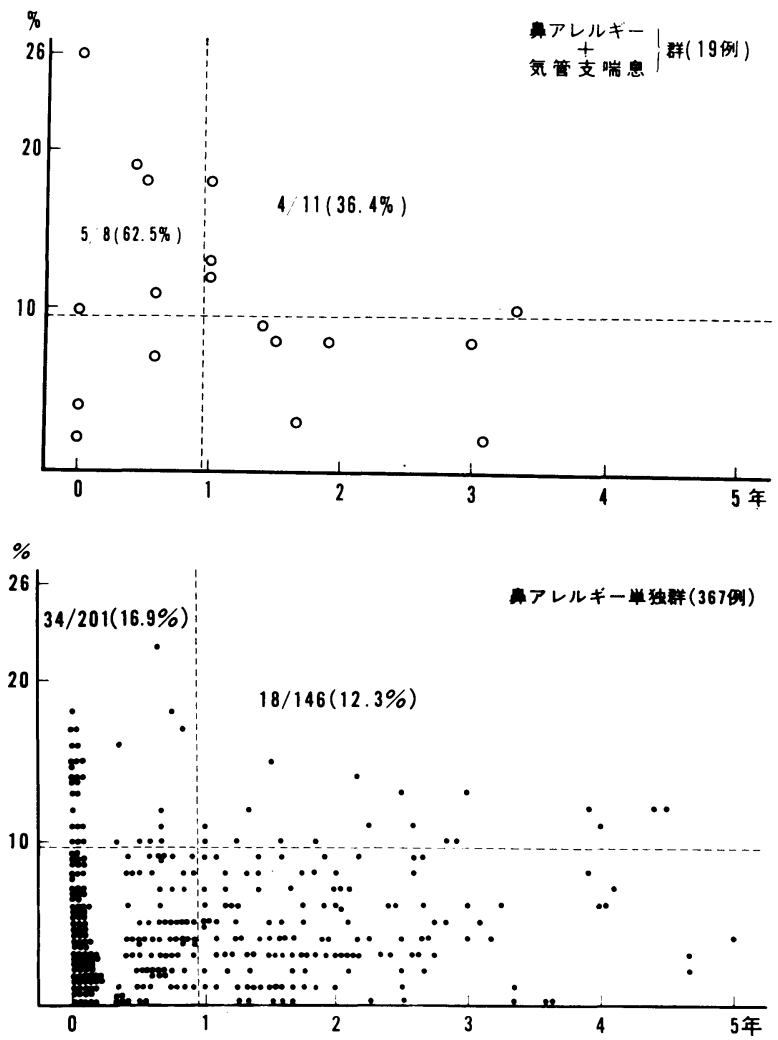

図 8 血中好酸球と治療期間

併群では $36.4 \%$ とかなりの減少傾向を認めた。

次に一元拡散法による血清 $\mathrm{IgE}$ 值と治療期 間との関係について検討した（図 9 ). 血清 $\operatorname{IgE}$ が1000単位以上の症例数は 1 年未満減感作治療 では単独群 $19.3 \%$ に比べ喘息合併群は $62.5 \%$ と有意に高く $(\mathrm{P}<0.025)$ ，乙れは 1 年以上減 感作治療を行っても変化せず合併群と単独群之 の間に有意差があった（ $\mathrm{P}<0.005 ）$ ，てのよう な傾向は既往群と単独群の間でも認められ 1 年 未満治療例で $\mathrm{P}<0.005,1$ 年以上治療例では $\mathrm{P}$ $<0.025$ とそれぞれとの 2 群間で有意であった.

RAST SCORE と治療期間の関係は図10に 示している. RAST SCORE 3 以上を示した症 例は, 1 年未満減感作治療では鼻アレルギー単 独群の $38.3 \%$ に比べ喘息合併群では $100 \%$ と有 意に高く（ $P<0.005 ）$ この傾向は喘息既往群 と鼻アレルギー単独群との間にも認められた。
しかし 1 年以上減感作治療を行っても特に有意 な変化は認めらず，合併群と単独群との間にも 有意差はなかった。

皮内反応を利用した遮断抗体の陽性率と治療 期間の関係は図11に示す。喘息合併群も喘息既 往群も 1 年以上減感作治療を続けるととにより 約 $50 \%$ 以上抗体の出現を認め，特に喘息既往 群においては，2.5\%の危険率で有意に高く鼻 アレルギー単独群においても $0.5 \%$ の危険率で 有意に高率であった。

自覚症状改善度と治療期間との関係について あ検討してみたが，喘息合併群では有効例が 1 年以上で $45.5 \%$, 鼻アレルギー単独群では 62.9 \%で幾分高率に見られたが，両者間に統計的有 意差は認められなかった。

鼻アレルギーの減感作治療中に喘息発作が誘 発されたと考えられるのは合併群, 既往群を合 

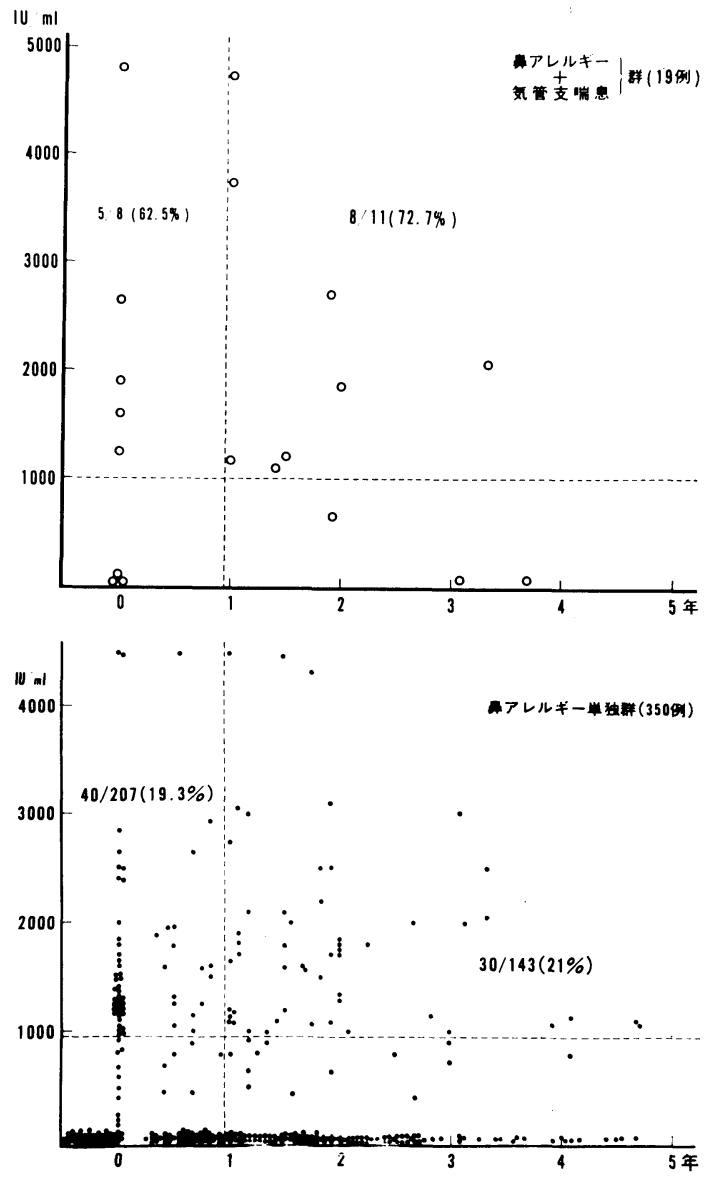

図 9 血清 $\operatorname{IgE}$ 值と治療期間

わせた 75 例中 4 例（5.3\%） に認めた。いずれ もハウスダストの 10 倍希釈液 $0.5 \mathrm{ml}$ 用いて維

考

鼻アレルギーと気管支喘息の合併率について はすでに種々報告されており，鼻アレルギーに

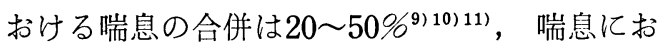

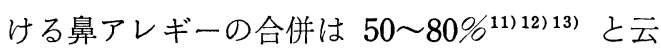
われている，著者等が今回研究の対象とした症 例は, 問診から専門医の診察を受け気管支喘息 と㟝断され現在治療中のもの, 以前に喘息発作 があり治療を受けたととがあるが，ての数年間 全く発作が起っていないものをそれぞれ喘息合 併群，喘息既往群として選び出した。喘息合併
持療法中に誘発され，治療開始後 4 ケ月から 2 年経過した症例であった。

按

群は $4.4 \%$ と諸家の報告に比べ著るしく低く， 又喘息既往群は $12.9 \%$ 合計 $17.3 \%$ が喘息を合 併むしくは合併したことのある群と云える。不 十分な問診あるいは記載漏れなどを考慮する と，喘息合併例は $17.3 \%$ よ幾分上まわると考 えられる.

さて鼻アレルギーの重症度や減感作治療効果 を喘息合併群又は既往群と鼻アレルギー単独群 とで比較する場合，パラメーターとしては一元 拡散法又はR I S T 法による血清 IgE 值, RA 

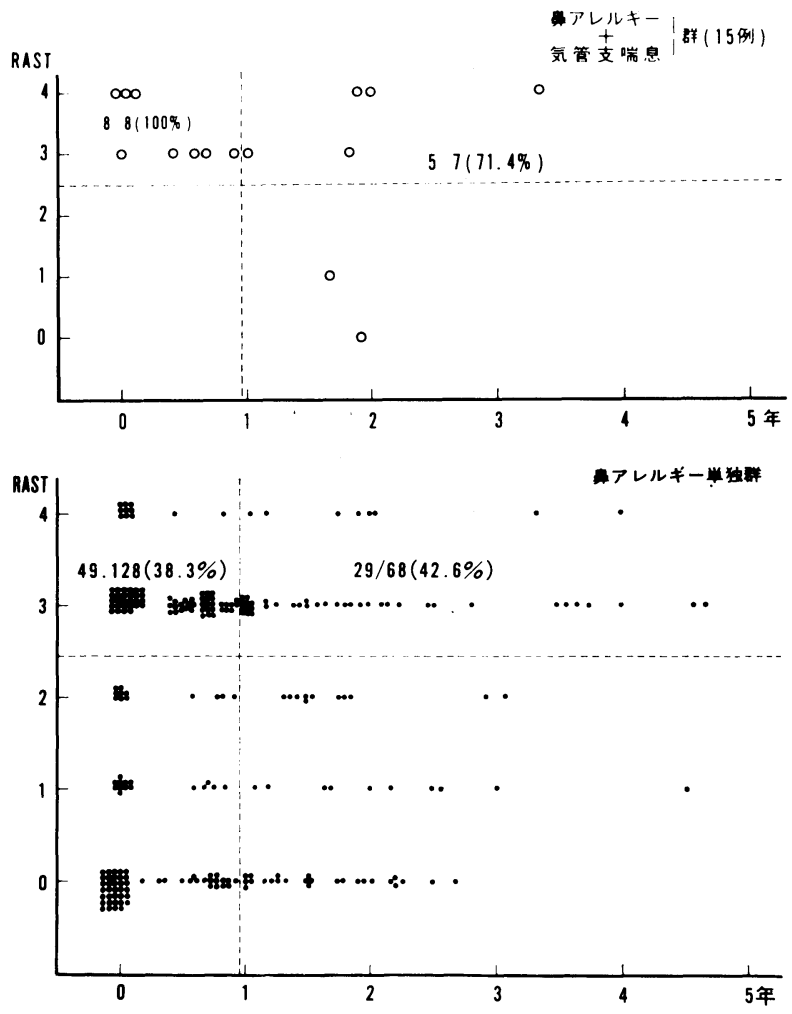

図10 RAST SCORE と治療期間
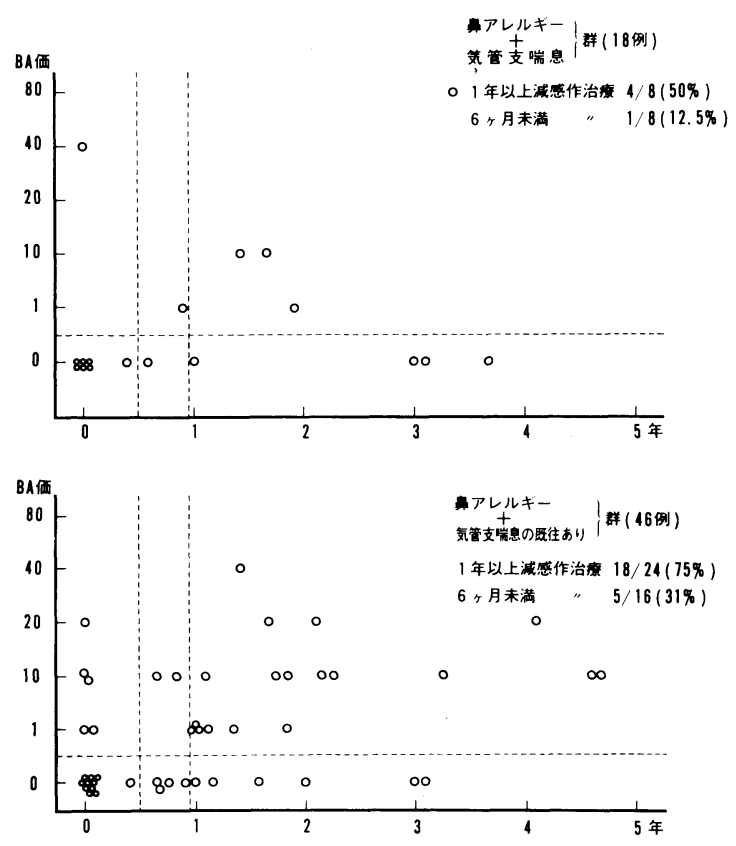

図II 遮断抗体陽性率と治療期間 
ST SCORE, 血中好酸球, 鼻汁中好酸球, 及び 自覚症状の 5 項目を用い，本研究では皮内反応 閾值試験，鼻粘膜誘発試験，鼻内局所所見等に ついては検討を加えなかったので幾分資料不足 であることは否定出来ない.

鼻アレルギーの重症度を，喘息合併群と鼻ア レルギー単独群との間で比較する場合，それぞ れのパラメーターについて検討するよりも R A $\mathrm{S} T$ と血清 $\mathrm{IgE}$, 血中好酸球と鼻汁中好酸球, 血清 $\operatorname{IgE}$ と血中好酸球というような密接に関 係しているパラメーターを組合わせて比較した 方がより明確な解答を得ることが出来るように 思える。

R I S T值が1000 I U以上, RAST SCORE が 3 以上を示した症例数の制合は図 6 に示した 如く，喘息合併群，既往群が鼻アレルギー単独 群に比べ有意に高い值を示した。 又一元拡散法 による血清 IgE 值が 1000 IU 以上で血中好酸 球が $10 \%$ 以上を示した症例の制合は, 初診時に おいて喘息合併群は鼻アレルギー単独群に比べ 有意に高值を示した（図 5 )。しかし血中好酸 球が $8 \%$ 以上で鼻汁中好酸球が十以上の症例の 割合は，初診時においてはいずれの群でも有意 差は認められなかった（図 4 ). 以上の結果よ り鼻アレルギーに気管支喘息を合併しておれ

ば，R I S T, R A S Tが共に高值を示す症例 や血清 IgE 值, 血中好酸球が共に高值を示す 症例がそれぞれ鼻アレルギー単独群に比べ多く 認められるが, 血中好酸球, 鼻汁好酸球が共に 高值を示す症例は両群間で差がないととが分っ た。つまり合併群では血中のパラメーターが共 に高值を示す症例が多いが，鼻内局所における パラメーターには影響されないととが推測され る. 合併群が鼻アレルギー単独群に比べ全身的 には重症であると推論してもよいのではないだ 万うか. 血清 $\mathrm{IgE}$ 值や血中好酸球, 皮内反応 閾值試験は shock organの大きさにより影響 され, 鼻アレルギー単独群ではほぼ正常範囲内 にあるが，喘息を合併すれば高值を示す傾向に
あるという Mygind の報告 ${ }^{14)}$ は我々の結果を 支持するあのと考えている.

次に鼻アレルギーにおける減感作治療効果に 気管支喘息の合併あるいは既往が如何なる影響 を与えているのか日常の鼻アレルギー外来を担 当する耳鼻科医にとって興味あるととろであ る. 我々の研究結果によれば 1 年以上の減感作 治療を行い有意に治療効果を認めたものは，鼻 アレルギー単独群の鼻汁好酸球数と遮断抗体陽 性率のみで，喘息合併群においても同様の傾向 が認められた(図 7，11)。しかし血中好酸球, 血清 IgE 值, RAST SCORE，自覚症状等にお いて両群間で 1 年以上の減感作を行っても治療 効果は認められなかった。 鼻アレルギー単独群 においてさえも，1 年以上の減感作治療により 変化しなかったパラメーターが多く見られたの は, 鼻粘膜誘発闇值試験, 鼻内局所所見等につ いて検討しなかったととと, shock organ の大

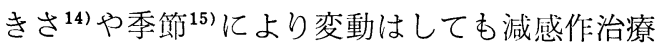
により影響を受けないと云われている血中好酸 球, 血清 IgE, RAST 等を比較の対象とした為 である. 鼻アレルギーの治療効果判定に最も決 め手となるパラメーターの 1 つに自覚症状の改 善度があるが，今回まとめた結果からは両群間 に有意差は認められなかった。このととは我々 が用いた自覚症状改善度の効果判定基準に問題 がないとは云えないが，自覚症状改善例におけ る他覚所見との不一致等, 減感作治療効果判定 の難しさが伺える，減感作治療により鼻汁中好 酸球数, 遮断抗体陽性率がいずれの群において あ有意差又はその傾向にあることから鼻アレル ギー単独群でも合併群でも鼻アレルギーに対す る鼻症状の治療効果は同程度にあるのではない だろうか.

以上のように鼻アレルギーの鼻症状は鼻アレ ルギー単独例と喘息合併例とで差異はなく, 減 感作治療を行えば鼻アレルギー単独群と同程度 の効果をあげうると考えられる。 


\section{ま と め}

昭和 53 年 1 月より 12 月までの 1 年間に三重大学耳鼻咽喉科アレルギー外来にて検査を受けた 435 名を対象に問診より喘息合併群, 喘息既往群, 鼻アレルギー単独群の 3 群に分類し一元拡散法又は R I S T法による血清 IgE 值, RAST SCORE, 血中好酸球, 鼻汁中好酸球, 自覚症状の 5 項目に ついて鼻アレルギーの重症度や減感作治療効果を検討した．その結果鼻アレルギーに気管支喘息を 合併しておればR I S T, R A S T が共に高值を示す症例や血清 IgE 值, 血中好酸球が共に高值 を示す症例がそれぞれ鼻アレルギー単独群に比べ多く認められたが, 血中好酸球, 鼻汁好酸球が共 に高值を示す症例は両群間で差がなかった。鼻アレルギーに対して 1 年以上の減感作治療を行い有 意に治療効果を認めたものは, 鼻アレルギー単独群の鼻汁好酸球と遮断抗体陽性率のみで, これらは 喘息合併群においても同様の傾向が認められた. しかし血中好酸球, 血清 IgE 值, RAST SCORE, 自覚症状等においては両群間で 1 年以上の減感作治療を行って屯治療効果は認められなかった。

本論文の要旨は第12回東海耳鼻咽喉科アレルギー㸸話会

(昭和54年 6 月 23 日)，及び第27回日耳鼻中部地方部 会連合会（昭和54年 7 月14日）において口演した。

\section{参考 文 献}

1) Gell PGH, Coombs RRA \& Lachmann R(eds) : Clinical Aspects of Immunology, 3 rd ed., Section IV. Blackwell Scientific Publications, Oxford, 1975.

2 ) Ishizaka $\mathrm{T}$, Sian $\mathrm{CM} \&$ Ishizaka $\mathrm{K}$ : Complement fixation by aggregated through alternate pathway. J Immunol $108: 848 \sim 851,1972$.

3 ) Kishimoto $\mathrm{T} \&$ Ishizaka $\mathrm{K}$ :. Regulation of antibody response in vitro. $\mathbb{N}$, Heavy chain antigenic determinants on haptenspecific memory cells. J Immunol 109 : 1163 1172, 1972.

4) Hubscher TT : Immune and biochemical mechanisms in the allergic disease of the upper respiratory tract; Role of antibodies, target cells, mediators and eosinophils. Ann Allergy $38: 83 \sim 90,1977$.

5 ) Criep LH : Etiology and pathophysiology of bronchial asthma. In allergy and clinical immunology. P. 242. Grune and Stratton, New York, 1976.

6 ）馬場実：小児科領域における気道アレルギ一性疾 患の治療一とくに小児喘息を中心にして一. 耳喉 $45:$ 155 161, 1973.

7）堀内淑彦：アレルギー疾患の最近の動向. 治療 $55: 635 \sim 639,1973$.

8 ）鵜飼幸太郎, 坂倉康夫, 由井誠一郎, 谷口知恵子,
三井洋, 伊藤由起子, 三吉康郎：血清遮断抗体に よる鼻アレルギー減感作療法の評価. 日耳鼻 82 : 463 469, 1979.

9）寺尾彬, 佐藤靖雄：アレルギー性鼻炎と気管支喘 息. 内科 15:869 874, 1965.

10）黒住静之, 林鷹治, 田中竜二, 海田智行, 天野大 輔, 粟谷昌一, 大成浄志：気道アレルギーにおけ る上気道, 下気道調節機構に関する考察. アレル ギー 2I: 441〜 456, 1972.

11）奥田稔：鼻アレルギーと気管支喘息. 気食会報 $27: 54 \sim 59,1976$.

12）水谷明, 高木健三, 大黒道夫, 近藤富雄, 熱田裕 ，伊藤和彦，水野勝之：東海地方における気管支

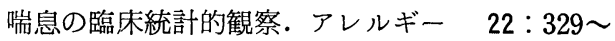
$340,1973$.

13）吉田亮, 般橋茂, 内田佐太臣, 奥田稔, 浅野佳徳 : 気管支喘患児の鼻所見並びに鼻粘膜誘発試験に ついて. 小児科臨床 21：644〜648，1968.

14) Mygind N : Nasal Allergy, lst ed. Chapter 15. Blackwell Scientific Publications, Oxford,1978

15）中村凱次, 吉田隆実: 減感作療法中の気管支喘息 患児の血清值の変動について．アレルギー 26 : 573 580, 1977.

\footnotetext{
/ 原稿到着：昭和55年 3 月19日 別刷請求先：鵜飼幸太郎 동 514 津市江分橋 2 丁目 174 三重大学医学部耳鼻咽喉科学教室
} 